\title{
Infections
}

\section{Genital mycoplasmal infections: their relation to prematurity and other abnormalities of reproduction}

\author{
WILLIAM M. MCCORMACK ${ }^{1}$ \\ From the Channing Laboratory, Departments of Medical Microbiology and Medicine, Boston City Hospital, \\ and the Department of Medicine, Harvard Medical School, Boston, Massachusetts
}

Mycoplasmas are a distinct group of microorganisms differing in important biological characteristics from bacteria, viruses, fungi, protozoa and chlamydia (McCormack et al,1973a).There are eight recognized species of mycoplasmas which have been isolated from man (table I). Mycoplasma pneumoniae, the Eaton agent, causes cold agglutinin-positive primary atypical pneumonia. $M$. salivarium, $M$. orale, $M$. buccale, and $M$. faucium are oropharyngeal commensals and have not as yet been convincingly implicated in any disease process (Freundt et al, 1974). M. fermentans is an unusual genital isolate which also appears to be a commensal. $M$. hominis and Ureaplasma urealyticum, also known as the T-mycoplasmas or T-strains, are common genital organisms (Shepard et al, 1974). Although $M$. hominis and $U$. urealyticum have been implicated in nongonococcal urethritis, pelvic inflammatory disease, and a number of other disorders, most interest in these organisms has centred around their possible involvement in disorders of reproduction. The purpose of this communication will be to review the evidence linking $M$. hominis and $U$. urealyticum to infertility, abortion, stillbirth, low birth weight, and puerperal fever.

\section{Epidemiological Considerations}

Basic to the understanding of the role of a microorganism in human disease is an understanding of the epidemiology of the organism, its mode of transmission and its prevalence among the normal population.

Genital mycoplasmas can be isolated from the

'S upported by research grant HD 03693 from the National Institute of Child Health and Human Development, and research grants AI 11363 and AI 12381 and training grant AI 00068 from the National Institute of Allergy and Infectious Diseases.

Please address reprint requests to Dr William M. McCormack, Cha nning Laboratory, Boston City Hospital, Boston, Massachusetts 02118.

\begin{tabular}{ll}
\hline Respiratory & Genital \\
\hline Mycoplasma pneumoniae & Mycoplasma hominis \\
Mycoplasma salivarium & Mycoplasma fermentans \\
Mycoplasma orale & Ureaplasma urealyticum \\
Mycoplasma buccale & \\
Mycoplasma faucium & \\
\hline
\end{tabular}

Table I Human mycoplasmal species

genitalia and upper respiratory tract of about $30 \%$ of newborn infants. These organisms are primarily acquired during passage through the birth canal; infants who are delivered by caesarian section are colonized less often than those who are delivered vaginally (Klein et al, 1969). Colonization does not persist throughout childhood. Only about $10 \%$ of girls between 1 and 10 years of age have mycoplasmas recovered from the genitourinary tract (Lee et al, 1974).

- Following puberty, sexual experience appears to be the primary determinant of colonization with both $M$. hominis and U. urealyticum (McCormack $e t$ $a l, 1972)$. Table II summarizes a study in which selfobtained vaginal cultures and anonymous questionnaires were obtained from a group of student and graduate nurses. Those who had not experienced genital contact had low rates of colonization, similar to those seen among young children. Among those who were sexually experienced, colonization with both $U$. urealyticum and $M$. hominis rose in relation to the number of sexual partners, reaching $75 \%$ and $16.7 \%$ among those who had had intercourse with three or more partners. It is against this background that we must view the evidence linking the genital mycoplasmas to disorders of reproduction.

\section{Infertility}

A series of reports from Sweden has suggested that 


\begin{tabular}{|c|c|c|c|}
\hline & Number of Women Studied & $\begin{array}{l}\text { Percentage with } \\
\text { U. urealyticum }\end{array}$ & $\begin{array}{l}\text { Percentage with } \\
\text { M. hominis }\end{array}$ \\
\hline $\begin{array}{l}\text { No genital contact } \\
\text { Genital contact without vaginal penetration } \\
\text { Sexual intercourse }\end{array}$ & $\begin{array}{l}71 \\
30\end{array}$ & $\begin{array}{r}5 \cdot 6 \\
26 \cdot 7\end{array}$ & $\begin{array}{l}1 \cdot 4 \\
0\end{array}$ \\
\hline $\begin{array}{l}\text { One partner } \\
\text { Two partners } \\
\text { Three of more partners }\end{array}$ & $\begin{array}{l}32 \\
11 \\
12\end{array}$ & $\begin{array}{l}37 \cdot 5 \\
54 \cdot 5 \\
75 \cdot 0\end{array}$ & $\begin{array}{r}9 \cdot 4 \\
9 \cdot 1 \\
16 \cdot 7\end{array}$ \\
\hline
\end{tabular}

Table II Relationship of sexual experience to vaginal colonization with genital mycoplasmas among student and graduate nurses

$U$. urealyticum might be an important cause of unexplained involuntary infertility. These workers found that infertile couples were colonized with $U$. urealyticum significantly more often than couples of normal fertility. Furthermore, in an uncontrolled study, treatment of colonized infertile couples with mycoplasmicidal antibiotics was associated with conception in about $30 \%$ of cases (Gnarpe and Friberg, 1973). In similar studies, Love et al (1973) have associated $M$. hominis with infertility.

More recently, de Louvois et al (1974) have reported that they isolated both $U$. urealyticum and $M$. hominis as often from fertile as from infertile couples, a finding which is in agreement with unpublished observations from our laboratory. The same group of investigators has conducted a controlled therapeutic trial in which couples with infertility of unascertained cause were randomly assigned to receive doxycycline, a placebo or no treatment. Although doxycycline eradicated both $M$. hominis and $U$. urealyticum, the rate of conception was no higher in those treated with the drug than in the control group. They concluded that mycoplasmas are not associated with primary infertility (Harrison et al, 1975). It should be noted that this negative study is the only properly controlled study in which the relationship of mycoplasmas to infertility has been assessed.

\section{Spontaneous Abortion and Stillbirth}

Genital mycoplasmas have been isolated from products of conception of early abortions (Caspi et al, 1972) and mid-trimester fetal losses (Sompolinsky et $a l, 1975)$ more often than from the products of conception of induced abortions. It is not clear from these reports whether the mycoplasmas were wholly or partially responsible for fetal death. It is equally likely that these organisms were able to invade the fetus and placenta once fetal death had occurred for other reasons.

Mycoplasmas have been isolated from the viscera and lungs of spontaneously aborted fetuses and stillborn infants. The isolation of mycoplasmas from fetal lungs probably represents aspiration of infected amniotic fluid whereas isolation from the viscera may be indicative of haematogenous spread, perhaps from a placentitis with invasion of the fetus via the umbilical vessels (McCormack et al, 1973a).

The possible association of mycoplasmal infection with fetal loss is of considerable interest and importance since these organisms are sensitive in vitro to tetracycline and other broad-spectrum antibiotics. Thus, fetal loss, if due to these organisms, could conceivably be prevented by appropriate antimicrobial therapy. It is unfortunate in this regard that there have been no controlled studies in which pregnant women with a history of fetal loss have been randomly assigned to receive antibiotic or placebo.

In an uncontrolled study, six women with a history of a total of 29 previous unsuccessful pregnancies, most of which had ended in spontaneous abortion during the first trimester, were treated with demethylchlortetracycline. Treatment began before or shortly after conception and continued through the 28th week of pregnancy. Four of the six patients gave birth to viable infants (Driscoll et al, 1969). These and other instances in which women with a poor reproductive history were found to be colonized with $U$. urealyticum and had successful pregnancies after treatment with tetracyclines have led this group of investigators to postulate that subclinical infection with mycoplasmas is an important cause of reproductive failure (Horne et al, 1974). Their hypothesis has been strengthened by the demonstration of inflammation in endometrial biopsies from women with a poor reproductive history who were infected with $U$. urealyticum (Horne et al, 1973). This area, however, remains controversial and well controlled therapeutic trials are urgently needed to settle the issue.

\section{Low Birth Weight}

The chain of events linking the genital mycoplasmas to birth weight began about 15 years ago. In studies conducted before the association of prenatal tetracycline administration to staining of the primary dentition was recognized, this antibiotic was 
administered to pregnant women. In each of two controlled, double-blind studies, treatment with tetracycline for six weeks was associated with a significant reduction in the prevalence of low birth weight infants (Elder et al, 1968; Elder et al, 1971). Although no microbiological examinations were performed, it was postulated that a tetracyclineresponsive microorganism might be responsible for some instances of low birth weight. The mycoplasmas were among the organisms which were considered.

The first direct evidence linking the genital mycoplasmas to birth weight came when Klein et al (1969) examined newborn infants. They found that infants were colonized with mycoplasmas in inverse relation to birth weight. Their data are summarized in table III.

A prospective study was then conducted in which cultures were obtained from 484 prenatal patients at the time of their first prenatal visit (Braun et al, 1971). As shown in table IV, women who were colonized with $U$. urealyticum gave birth to infants who weighed significantly less than infants born to women who were not colonized. Colonization with $M$. hominis was also related to birth weight although the association was less striking. Another group of investigators has also noted an association between maternal colonization with $M$. hominis and low birth weight (Di Musto et al, 1973). They did not examine for $U$. urealyticum.

One mechanism by which infection might play a role in low birth weight would be to cause inflammation of the placenta and fetal membranes. In this

\begin{tabular}{llll}
\hline $\begin{array}{l}\text { Birth Weight } \\
(\mathrm{g})\end{array}$ & $\begin{array}{l}\text { Number of } \\
\text { Infants } \text { Studied }\end{array}$ & $\begin{array}{l}\text { Number } \\
\text { Colonized }\end{array}$ & $\begin{array}{l}\text { Percentage } \\
\text { Colonized }\end{array}$ \\
\hline 1500 or less & 3 & 3 & 100 \\
$1501-2000$ & 16 & 5 & 31 \\
$2001-2500$ & 49 & 7 & 14 \\
$2501-3000$ & 47 & 7 & 15 \\
$3001-3500$ & 69 & 8 & 12 \\
over 3500 & 37 & 3 & 8 \\
\hline
\end{tabular}

Table III Relationship of mycoplasmal colonization of newborn infants to birth weight

${ }^{1} M$. hominis and/or $U$. urealyticum isolated from nose and/or throat regard, the recent study of Shurin et al (1975) suggesting that a substantial proportion of cases of chorioamnionitis may be caused by $U$. urealyticum is of considerable interest. These data are summarized in table $\mathrm{V}$.

It is not possible to conclude from these data that $U$. urealyticum and $M$. hominis are a cause of low birth weight. The data, however, are highly suggestive of such a relationship, and, considering the importance of low birth weight in perinatal morbidity and mortality, would seem to warrant further investigation.

\section{Septic Abortions and Puerperal Infections}

As is the case with most of the organisms which comprise the vaginal flora, the mycoplasmas are capable of invading the uterus and the blood stream following abortion or following delivery. $M$. hominis can be isolated from the blood of 5 to $10 \%$ of women with otherwise unexplained fever following abortion (Harwick et al, 1970) and following delivery (McCormack et al, 1973b). These patients characteristically develop low-grade fever a day or two following delivery, do not appear severely ill, and recover uneventfully even in the absence of mycoplasmacidal antibiotics. Gram-stained smears of endocervical aspirates contain many polymorphonuclear leucocytes without bacteria (Wallace et al, 1976). $U$. urealyticum has only rarely been isolated from the blood of women with postpartum fever (Sompolinsky et al, 1971).

Thus, it seems clear that $M$. hominis, and to a lesser extent $U$. urealyticum, can be isolated from the blood of a few women with fever following delivery. What remains to be established is the frequency of uterine invasion without blood stream invasion and the relative contribution of mycoplasmal endometritis to the entire spectrum of postabortal and postpartum fever.

\section{Summary}

The genital mycoplasmas, Mycoplasma hominis and

\begin{tabular}{|c|c|c|c|c|c|}
\hline & \multicolumn{2}{|c|}{ U. urealyticum } & & \multicolumn{2}{|c|}{ M. hominis } \\
\hline & Number & $\begin{array}{l}\text { Mean Birth } \\
\text { Weight }(g)\end{array}$ & & Number & $\begin{array}{l}\text { Mean Birth } \\
\text { Weight }(g)\end{array}$ \\
\hline $\begin{array}{l}U . \text { urealyticum isolated } \\
\text { U. urealyticum not isolated }\end{array}$ & $\begin{array}{l}384 \\
100 \\
P<0.00\end{array}$ & $\begin{array}{l}3099 \\
3297\end{array}$ & $\begin{array}{l}\text { M. hominis isolated } \\
\text { M. hominis not isolated }\end{array}$ & $\begin{array}{l}229 \\
255 \\
P=0.054\end{array}$ & $\begin{array}{l}3084 \\
3187\end{array}$ \\
\hline
\end{tabular}

Table IV Birth weight and colonization with genital mycoplasmas during pregnancy 


\begin{tabular}{lll}
\hline & \multicolumn{2}{l}{ T mycoplasmas } \\
\cline { 2 - 3 } Chorioamnionitis & Isolated & Not Isolated \\
\hline None & $22(19 \%)$ & $94(81 \%)$ \\
$1+$ & $14(20.6 \%)$ & $54(79.4 \%)$ \\
$2+$ or $3+$ & $18(37.5 \%)$ & $30(62.5 \%)$ \\
\hline
\end{tabular}

Table V Chorioamnionitis and colonization of newborn infants with genital mycoplasmas

Ureaplasma urealyticum (T-mycoplasmas) are common vaginal organisms. They are acquired primarily through sexual contact. There is evidence, some of it highly suggestive, linking the genital mycoplasmas to involuntary infertility, spontaneous abortion and low birth weight. Additional controlled treatment studies are needed in each of these areas to assess fully the role of the genital mycoplasmas. $M$. hominis has the potential to invade the blood stream and is responsible for some instances of fever following abortion and of postpartum fever.

\section{References}

Braun, P., Lee, Y. H., Klein, J. O., Marcy, S. M., Klein, T. A., Charles, D., Levy, P., and Kass, E. H. (1971). Birth weight and genital mycoplasmas in pregnancy. New Engl.J. Med., 284, 167-171.

Caspi, E., Solomon, F., and Sompolinsky, D. (1972). Early abortion and Mycoplasma infection. Israel J. med. Sci., 8, 122-127.

Di Musto, J. C., Bohjalian, O., and Millar, M. (1973). Mycoplasma hominis type I infection and pregnancy. Obstet. and Gynec., 41, 33-37.

Driscoll, S. G., Kundsin, R. B., Horne, H. W., Jr., and Scott, J. M. (1969). Infections and first trimester losses: possible role of mycoplasmas. Fertil. and Steril., 20, 1017-1019.

Elder, H. A., Santamarina, B. A. G., Smith, S. A., and Kass, E. H. (1971). The natural history of asymptomatic bacteriuria during pregnancy: the effect of tetracycline on the clinical course and the outcome of pregnancy. Amer. J. Obstet. Gynec., 111, 441-462.

Elder, H. A., Smith, R., and Kass, E. H. (1968). Presented at the Eighth Interscience Conference on Antimicrobial Agents and Chemotherapy, New York.

Freundt, E. A., Taylor-Robinson, D., Purcell, R. H., Chanock, R. M., and Black, F. T. (1974). Proposal of Mycoplasma buccale nom. nov. and Mycoplasma faucium nom. nov. for Mycoplasma orale 'types' 2 and 3, respectively. Int. J. syst. Bact., 24, 252-255.

Gnarpe, H., and Friberg, J. (1973). T-mycoplasmas as a possible cause for reproductive failure. Nature (Lond.), 242, 120-121.
Harrison, R. F., de Louvois, J., Blades, M., and Hurley, R. (1975). Doxycycline treatment and human infertility. Lancet, 1, 605-607.

Harwick, H. J., Purcell, R. H., Iuppa, J. B., and Fekety, F. R., Jr. (1970). Mycoplasma hominis and abortion. J. infect. Dis., 121, 260-268.

Horne, H. W., Hertig, A. T., Kundsin, R. B., and Kosasa, T. S. (1973). Sub-clinical endometrial inflammation and $T$ mycoplasma. A possible cause of human reproductive failure. Int. J. Fertil., 18, 226-231.

Horne, H. W., Kundsin, R. B., and Kosasa, T. S. (1974). The role of mycoplasma infection in human reproductive failure. Fertil. and Steril., 25, 380-389.

Klein, J. O., Buckland, D., and Finland, M. (1969). Colonization of newborn infants by mycoplasmas. New Engl. J. Med., 280, 1025-1030.

Lee, Y. H., McCormack, W. M., Marcy, S. M., and Klein, J. O. (1974). The genital mycoplasmas: their role in disorders of reproduction and in pediatric infections. Pediat. Clin. $N$. Amer., 21, 457-466.

de Louvois, J., Blades, M., Harrison, R. F., Hurley, R., and Stanley, V. C. (1974). Frequency of Mycoplasma in fertile and infertile couples. Lancet, 1, 1073-1075.

Love, W., Jones, M., Andrews, B., and Thomas, M. (1973). Mycoplasmas in human infertility. (Letter.) Lancet, 1, 1130-1131.

McCormack, W. M., Almeida, P. C., Bailey, P. E., Grady, E. M., and Lee, Y. H. (1972). Sexual activity and vaginal colonization with genital mycoplasmas. J. Amer. med. Ass., 221, 1375-1377.

McCormack, W. M., Braun, P., Lee, Y. H., Klein, J. O., and Kass, E. H. (1973). The genital mycoplasmas. New Engl. J. Med., 288, 78-89.

McCormack, W. M., Lee, Y. H., Lin, J. S., and Rankin, J. S. (1973). Genital mycoplasmas in postpartum fever.J. infect. Dis., 127, 193-196.

Shepard, M. C., Lunceford, C. D., Ford, D. K., Purcell, R. H., Taylor-Robinson, D., Razin, S., and Black, F. T. (1974). Ureaplasma urealyticum gen. nov., sp. nov.: proposed nomenclature for the human $T$ ( $T$ strain) mycoplasmas. Int. J. syst. Bact., 24, 160-171.

Shurin, P. A., Alpert, S., Rosner, B., Driscoll, S. G., Lee, Y. H., McCormack, W. M., Santamarina, B. A. G., and Kass, E. H. (1975). Chorioamnionitis and colonization of the newborn infant with genital mycoplasmas. New Engl. J. Med., 293, 5-8.

Sompolinsky, D., Solomon, F., Elkina, L., Weinraub, Z. Bukovsky, I., and Caspi, E. (1975). Infections with mycoplasma and bacteria in induced midtrimester abortion and fetal loss. Amer.J. Obstet. Gynec., 121, 610-616.

Sompolinsky, D , Solomon, F., Leiba, H., Caspi, E., Lewinsohn, G., and Almog, C. (1971). Puerperal sepsis due to T-strain mycoplasma. Israel J. med. Sci., 7, 745-748.

Wallace, R. J., Alpert, S., Browne, K., and McCormack, W. M. (1976). Postpartum fever associated with positive blood cultures for Mycoplasma hominis (mycoplasmemia). Clin. Res., 24, 27A. 